Trinity University

Digital Commons @ Trinity

Religion Faculty Research

Religion Department

2014

\title{
The Rape that Woke Up India: Hindu Imagination and the Rape of Jyoti Singh Pandey
}

C. Mackenzie Brown

Trinity University, mbrown@trinity.edu

Nupur D. Agrawal

Trinity University, nagrawal@trinity.edu

Follow this and additional works at: https://digitalcommons.trinity.edu/relig_faculty

Part of the Religion Commons

\section{Repository Citation}

Brown, M. C. \& Agrawal, N. (2014). The rape that woke up India: Hindu imagination and the rape of Jyoti Singh Pandey. Journal of Religion and Violence, 2(2), 234-280. doi: 10.5840/jrv2014222

This Post-Print is brought to you for free and open access by the Religion Department at Digital Commons @ Trinity. It has been accepted for inclusion in Religion Faculty Research by an authorized administrator of Digital Commons@ Trinity. For more information, please contact jcostanz@trinity.edu. 
The Rape that Woke Up India: Hindu Imagination and the Rape of Jyoti Singh Pandey

C. Mackenzie Brown and Nupur D. Agrawal

Trinity University, San Antonio, Texas

"Wake up India. She is dead." Thus exhorted a giant billboard on the Delhi-Gurgaon expressway only days after the death of a twenty-three-year-old physiotherapy student, Jyoti Singh Pandey, on December 29, 2012 (see Fig. 1). The expressway proclamation was part of an unprecedented protest by men and women challenging commonly accepted cultural, political, juridical, and social assumptions and practices regarding the position of women in contemporary Indian society. ${ }^{1}$ Such assumptions and practices, the billboard implied, lay behind the gang-rape and mutilation of Jyoti Pandey on December 16, 2012.

\footnotetext{
${ }^{1}$ See Urvashi Bulaia, “Let's Ask How We Contribute to Rape,” The Hindu, October
} 2, 2013, http://www.thehindu.com/opinion/op-ed/lets-ask-how-we-contribute-torape/article4235902.ece; Sonia Faleiro, “The Unspeakable Truth about Rape in India,” New York Times, January 1, 2013, http://www.nytimes.com/2013/01/02/opinion/theunspeakable-truth-about-rape-in-india.html?ref=opinion\&_r=0; Sohaila Abdulali, "I Was Wounded; My Honor Wasn’t,” New York Times, January 07, 2013, http://www.nytimes.com/2013/01/08/opinion/after-being-raped-i-was-wounded-myhonor-wasnt.html; Shoma Chaudhury, "The Girl Who Fired an Outcry in India," Tehelka.com, April 04, 2013, http://www.tehelka.com/the-girl-who-fired-an-outcry-inindia/; Amartya Sen, "India's Women: The Mixed Truth," The New York Review of Books, October 10, 2013, http://www.nybooks.com/articles/archives/2013/oct/10/indiaswomen-mixed-truth/. 
The assault occurred around 9:30 p.m., when Jyoti and her twenty-eight-year-old male companion, Awindra Pratap Pandey, a software engineer, were returning home after seeing a movie in South Delhi. Beckoned by the driver of a private bus and anxious to get home so her mother would not worry, Jyoti urged Awindra to board. Knowing the dangers for women riding such buses, Awindra was apprehensive but thought he could protect her if trouble arose. ${ }^{2}$ On the bus were five male friends of the driver posing as passengers. All were marginalized, low-status young men with little chance of realizing their dreams of a better life. During the day they had been drinking and planned to have some excitement that evening to escape the tedium and squalor of their lives. They had already enticed a man onto the bus earlier, stolen his phone and wallet and dumped him on the street. After the movie-goers boarded the bus, the passengers started taunting the couple, asking why Jyoti was out so late. Awindra attempted to defend her, but was beaten unconscious, his leg broken. The passengers and driver then assaulted Jyoti, raping her in turn, biting her body, and shoving a metal rod, apparently a rusty tire iron, up her vagina to her diaphragm. ${ }^{3}$ In a final act of brutality, the youngest attacker, a minor,

\footnotetext{
${ }^{2}$ Sandra Schulz and Wieland Wagner, "Rape Tragedy in India: Dreams of "the Fearless One,"” Spiegel Online International, January 25, 2013, http://www.spiegel.de/international/world/exploring-the-lives-of-the-rape-victim-andsuspects-in-india-a-879187.html.

${ }^{3}$ For Jyoti’s account of the attack, see Alex Marin, “Jyoti Singh Pandey: Gang Rape Victim Dying Declaration to Doom Perpetrators," PolicyMic, January 12, 2013, http://www.policymic.com/articles/22727/jyoti-singh-pandey-gang-rape-victim-dyingdeclaration-to-doom-perpetrators, and Dean Nelson, "Delhi Gang-rape Victim to Haunt
} 
tore out her intestines by hand and at his suggestion they dumped Jyoti and her friend onto the street naked. ${ }^{4}$ [FIGURE 1]

One of us (Brown) was in India at the time. After reading newspaper accounts of the attack and seeing the expressway billboard on the road to Jaipur, he decided to go to the protests taking place near India Gate in Delhi. Brown visited the protestors on January 11, 2013, almost two weeks after Jyoti's death; at this point, the intense confrontations with police had died down. Dozens of non-violent protestors milled around an altar with a make-shift image of Jyoti, tears of blood streaming over her cheeks, reflecting the grief of the nation (see Fig. 2). Nearby two men lay on the ground wrapped in blankets against the chilly winter air, fasting in protest (see Fig. 3). Beside them other protestors chanted "We want justice," in English and Hindi. On one side hung a large poster imploring the courts to "Hang the rapists." [FIGURES 2 AND 3]

When Brown returned to the U.S., the story of Jyoti would not leave him. Long interested in issues of gender and religious mythology in the Hindu tradition, he decided to investigate aspects of sexual assault in India today within the context of traditional cultural expectations for women. He recruited an undergraduate student, Nupur Agrawal,

Attackers with 'Dying Declaration,”' The Telegraph, January 11, 2013, http://www.telegraph.co.uk/news/worldnews/asia/india/9796076/Delhi-gang-rape-victimto-haunt-attackers-with-dying-declaration.html.

${ }^{4}$ See Jatin Anand, "Delhi Rape: Juvenile Raped Woman Twice and Ripped Off Her Intestine," Hindustan Times, January 03, 2013, http://www.hindustantimes.com/indianews/chunk-ht-ui-indiasectionpage-delhigangrape/delhi-rape-juvenile-raped-womantwice-and-ripped-off-her-intestine/article1-984188.aspx. 
a native of Gujarat, to conduct field research in North India regarding contemporary Indian attitudes towards rape and related issues. ${ }^{5}$ They designed a survey and set of interview questions that Agrawal took to India in the summer of 2013, where she visited ten universities and institutions (see Fig. 4). ${ }^{6}$ She conducted interviews with approximately seventy college-age men and women, and obtained 575 surveys. $^{7}$

In designing the survey and interview questions, Brown and Agrawal were especially interested in the extent to which traditional imaginings, including scriptural portrayals, of women and women's nature persist in the imaginations of young, collegeage students regarding gender relations. Pertinent data from the field study will be cited below to illustrate and illuminate the various topics we have chosen to discuss in this essay. [FIGURE 4]

\section{God-men and politicians on the rape of Jyoti Singh Pandey}

\footnotetext{
${ }^{5}$ In addition to the research project, Brown established a new course at his university for entering first-year students entitled "Rape in India, Rape in America, and Rape at Trinity.”

${ }^{6}$ There were 12 demographic and 27 substantive questions in the survey. The substantive questions employed a 5-point Likert scale. The interview questions were similar but open-ended. Readers interested in further details of the survey may contact the authors at mbrown@trinity.edu or nagrawal@ trinity.edu.

${ }^{7}$ The project was made possible by a grant from the Mellon Foundation for conducting summer undergraduate research.
} 
Important aspects of the cultural and social assumptions regarding contemporary women in India were quickly revealed in the religiously charged comments by politicians and spiritual leaders following the death of Jyoti. The swami Asaram Bapu, an extremely wealthy, self-proclaimed "divine incarnation" followed by millions, during a religious discourse to his devotees about how to avoid violent crime like sexual assault, proclaimed in a much-quoted statement that Jyoti

should have taken God's name and could have held the hand of one of the men and said I consider you as my brother and should have said to the other two, "Brother I am helpless, you are my brother, my religious brother.” She should have taken God's name and held their hands and feet...then the misconduct wouldn't have happened. ${ }^{8}$

The swami further explained that "[i]f the girl had chanted hymns to Goddess Saraswati and to Guru Diksha then she wouldn't have entered the bus...." ${ }^{9}$ These comments followed his most explicit victim-blaming decree: "Only 5-6 people are not the culprits. The victim daughter [Jyoti] is as guilty as her rapists...."

8 “Delhi Gangrape: Asaram Bapu Holds Girl Responsible, Says 'Spare' Rapists, Slams Media," The Indian Express, March 11, 2013, http://archive.indianexpress.com/news/asaram-bapu-holds-victim-responsible-for-delhigangrape/1055639/.

9 "Delhi gangrape: Asaram Bapu."

10 "Delhi Gangrape Victim as Guilty as Rapists: Asaram Bapu," Firstpost.India, January 07, 2013, http://www.firstpost.com/india/delhi-gangrape-victim-as-guilty-asrapists-asaram-bapu-579560.html. 
In addition to invoking religious practice and rhetoric as a means to prevent rape, some politicians cited scripture in another religiously modulated mode of victim-blaming. For instance, the Industry Minister of Madhya Pradesh and conservative member of the Bharatiya Janata Party, Kailash Vijayvargiya, cited the story of Rama's wife, Sita, and her abduction by Ravana in the Hindu epic, Ramayana, to implicate Jyoti in her own assault. In the epic, while Rama, Sita, and Rama's brother Lakshmana, were living in the forest, Ravana's henchman lured first Rama and then Lakshmana away from their encampment. Not wanting to leave Sita alone, Lakshmana drew a charmed line around her, protecting her as long as she did not cross it. With the brothers gone, Ravana saw his chance and approached in the guise of a religious mendicant, begging food. Acquiescing to the mendicant's demand that to honor him properly she needed to cross over the line, the "Lakshman rekha," Sita was immediately seized and carried off by Ravana. Lakshman's physical line has come to represent in modern times a moral boundary not to be crossed.

Vijayvargiya, inspired by this story, accused Jyoti of transgressing proper limits: "There is only one phrase for this and that is 'moral limit'; there is a lakshman rekha for every person, when that is crossed then the demon-king Raavan will abduct Goddess Sita." 11 He further explained, "One has to abide by certain moral limits. If you cross this

\footnotetext{
${ }^{11}$ Rama Lakshmi, “Amid Rape Fiasco, India’s Leaders Keep Up Insensitive Remarks," The Washington Post, January 04, 2013, http://www.washingtonpost.com/blogs/worldviews/wp/2013/01/04/amid-rape-fiascoindias-leaders-keep-up-insensitive-remarks/.
} 
limit you deserve to be punished. Just like Sita was abducted by Ravana." ${ }^{12}$ In an attempt to be even-handed, Vijayvargiya concluded that such limits apply to both men and women. The irony here is that Sita, in crossing the Lakshman Rekha, was treating the disguised Ravana fully in accord with sacred tradition, as a divine guest, an embodiment of a god. ${ }^{13}$ In contrast, Ravana and the six rapists of Jyoti violated the traditional Hindu ideal that the body is a temple never to be desecrated.

In the midst of such victim-blaming commentary, something unprecedented, however, occurred. As Shoma Chaudhury, a founding member of the investigative news magazine Tehelka notes, comments like those of Asaram Bapu and Vijayvargiya were ridiculed by many, especially the young:

India has a galling history of blaming women for the violence that happens to them. But now, when an older generation tried to mouth venal idiocies about how women should be chaste and cautious, the young turned on them with fierce scorn. ${ }^{14}$ But Chaudhury also adds the telling point,If they had been alone-a marginal raft of

\footnotetext{
12 "BJP Leader Quotes Ramayana, Says Women Who Cross Limits Pay the Price," IBN Live, January 04, 2013, http://ibnlive.in.com/news/bjp-leader-quotes-ramayana-sayswomen-who-cross-limits-pay-the-price/313761-37-64.html.

${ }^{13}$ For this insight we thank Raj Balkaran, University of Calgary, personal conversation, November 24, 2014.

${ }^{14}$ Chaudhury, "The Girl Who Fired an Outcry."
} 
clumsy old men—mere derision would have been enough. But the fear is, they are signposts of a much wider and deeper mindset. ${ }^{15}$

Indeed, Vijayvargiya won his sixth regional assembly election in a row on December 13, $2013 .^{16}$

The authors' survey also suggests that Chaudhury's fear is justified. In the survey, $24 \%$ of women strongly agreed $(4 \%)$ or agreed $(20 \%)$ that women who cross traditional limits (the so-called Lakshman Rekha) are at least partially responsible for what happens to them. Not surprisingly, even more men, $46 \%$, strongly agreed (14\%) or agreed (32\%) with Vijayvargiya (see Fig. 5). How these notions are actually applied in real life, however, is more complicated. In contrast to the relatively high level of agreement that an assaulted woman is at least partially responsible for crossing moral limits when considered in the abstract, far fewer held Jyoti responsible for the attack that took her life. While still distressingly high, a much smaller minority, $14 \%$ of women and $17 \%$ of men, either agreed or strongly agreed that Jyoti was primarily responsible for the attack that took her life (see Fig. 6). [FIGURES 5 AND 6]

A related issue regarding the supposed transgression of traditional limits is the extent to which western culture is contributing to the erosion of time-honored Indian values. The chief of the nationalist conservative RSS, Mohan Bhagwat, argued just days

\footnotetext{
${ }^{15}$ Shoma Chaudhury, “Rape, and How Men See It,” Tehelka.com, January 19, 2013, http://www.tehelka.com/cover-story-rape-and-how-men-see-it/.

16 “MP Minister Kailash Vijayvargiya Wins Sixth Election in Row,” Zeenews, December 08, 2013, http://zeenews.india.com/assembly-elections-2013/madhya-pradeshpolls/mp-minister-kailash-vijayvargiya-wins-sixth-election-in-row_895311.html.
} 
after Jyoti's death that "Such crimes [as rape] hardly take place in 'Bharat', but they occur frequently in 'India.", "Bharat" is the traditional name for India and its village culture, so as Bhagwat railed:

You go to villages and forests of the country and there will be no such incidents of gangrape [sic] or sex crimes. They are prevalent in some urban belts. Besides new legislations, Indian ethos and attitude towards women should be revisited in the context of ancient Indian values. ${ }^{18}$

Bhagwat specifically blamed the western lifestyle of urban Indians for the prevalence of rape in cities. Bhagwat's comment is obtuse. An editorial in India Today simply noted that Bhagwat displays "a bizarre ignorance of rural India." 19

Yet, in our survey, many respondents, both male and female, were inclined to agree with Mohan Bhagwat's assessment. We asked if rape in India is more an urban than a rural problem, and $56 \%$ of all respondents strongly agree or agreed, while only $25 \%$ disagreed or strongly disagreed (see Fig. 7). As for rape being "largely the result of

\footnotetext{
17 "RSS Chief Criticised for 'Rapes Happen in India, Not Bharat,"” Firstpost.Politics, January 04, 2013, http://www.firstpost.com/politics/rss-chief-criticized-for-rapes-happenin-india-not-bharat-comment-577946.html?utm_source=ref_article.

18 "RSS Chief Criticised."

19 "Rapes Happen in India, Not Bharat: RSS Chief Mohan Bhagwat Blames Western Culture for Gangrapes," Indiatoday, January 04, 2013, http://indiatoday.intoday.in/story/rapes-happen-in-india-not-bharat-rss-chief-mohanbhagwat-blames-western-culture-for-gangrapes/1/240709.html.
} 
western influences on Indian society," $48 \%$ agreed or strongly agreed, while $38 \%$ disagreed or strongly disagreed (see Fig. 8). [FIGURES 7 AND 8].

If the erosion of Indian values is a significant contributing factor for rape, as Bhagwat claims, then we need to look closely at what those values were, especially as they relate to issues of gender, and examine how they are interpreted today. Those values as reflected in traditional Hindu stories do not speak with one voice, expressing ambivalent ideals for women in ways that men like Bhagwat would probably wish to deny.

\section{Women in classical Hindu imagination}

We will look specifically at various scriptural and sacrosanct accounts of women in the epics, Puranas, and The Laws of Manu. We include stories of goddesses as well as of women, as the boundary between divine and human in the Hindu imagination is often blurred. At this point we simply note that in our survey, in response to the question whether or not "[T] he characterization of women and woman's nature in sacred scriptures contributes to rape tolerant attitudes," $34 \%$ of women and $41 \%$ of men agreed or strongly agreed (see Fig. 9). [FIGURE 9]

\section{Problematic portrayals of women in scripture and ancient traditions}

Let us turn first to the Indian epics, the Ramayana and the Mahabharata. Five stories in these texts, according to noted feminist journalist Nilanjana Roy, are especially 
relevant to issues of sexual assault. ${ }^{20}$ In the Mahabharata there is, first, the gambling away of Draupadi by her husband, as if she were his property, followed by a public assault on her dignity by an attempted disrobing of her while in her menses in front of the clan councils-fortunately to be rescued from this humiliation by Krishna. ${ }^{21}$

Second is Bhisma's abduction of Amba (along with her two sisters) for the purpose of securing wives for his step-brother Vichitravirya, in order to maintain the royal lineage. But Amba had already chosen another king, Salva, for her husband. Bhishma, one of the great heroes of the epic, allowed her to go to Salva, but Salva refused her as she had been sullied by Bhishma's touch and he harbored doubts about her purity. On returning to Bhishma's party, Amba was in turn rejected by Vichitravirya, and could find no one to marry her, since she had chosen another. Amba eventually takes revenge on Bhishma, committing suicide so that she could become a man in her next life and thus fight and destroy her abductor.

The third story from the Mahabharata concerns Amba's sisters, Ambika and Ambalika. Along with Amba, they were abducted by Bhishma in order to provide wives for Vichitravirya. Shortly after Ambika's and Ambalika's marriage to Vichitravirya, the latter died without an heir. But all hope for the royal dynasty was not lost, since the half-

\footnotetext{
${ }^{20}$ Nilanjana Roy, "Speaking Volumes: A Woman Alone in the Forest," nilanjanaroy.com, January 08, 2013, http://nilanjanaroy.com/2013/01/08/speakingvolumes-woma-in-the-forest/.

${ }^{21}$ For a retelling of Draupadi's disrobing in a contemporary context, see Mahasveta Devi, "Draupadi," trans. Gayatri Chakravorty Spivak, Critical Inquiry, 8, no. 2 (1981): 381-402.
} 
brother of Vichitravirya, the sage Vyasa, was called in to provide the necessary seed according to the tradition of niyoga, whereby a widow may conceive a child with the help of an approved surrogate father. The two widows, duty-bound as it were, submit to the sage but both are repulsed by him. Roy refers to these unions as "sanctioned rapes."

In the Ramayana, the episodes of the mutilation of the demonness Surpanakha and the abduction of Sita, already noted, are particularly revealing. Surpanakha, so the story goes in its various retellings, was wandering alone in the forest when she happened upon Rama and Lakshmana, falling instantly in love with them. Approaching them in a sexually provocative manner, she proposed marrying one, then the other. After being teased and mocked in turn by the two brothers, Surpanakha became desperate, threatening to eat Sita. And then the heroes swung into action: Rama ordered Lakshmana to punish her, and the dutiful brother proceeded to cut off her ears and nose, and depending on the version, even her hands, feet, nipples or breasts. ${ }^{22}$ Roy concludes that regardless of the version, the lesson is the same and is "in line with the contemporary warnings handed out to women in India: if you assume that you are free to roam everywhere, even in the forests, you will be hurt by the most ostensibly chivalrous of men."

\footnotetext{
${ }^{22}$ Kathleen Erndl, "The Mutilation of Surpanakha," in Many Ramayanas, The Diversity of a Narrative Tradition in South Asia, ed. Paula Richman (Berkeley: University of California Press, 1991), 74-75, 82-83, http://publishing.cdlib.org/ucpressebooks/view?docId=ft3j49n8h7\&chunk.id=d0e4061\&t oc.. epth $=1 \&$ toc.id=d0e $4061 \&$ brand=eschol.
} 
The Indian scholar Veena Talwar Oldenburg grew up hearing the Ramayana tales variously told to her by her grandmother, mother, and nanny. She also remembers observing the dramatic performance of Rama's life (Ramlila) in Delhi as a young girl. The version of the Ramayana she was exposed to was primarily the popular Hindi version, the Ramcaritamanas by Tulsidas. Oldenburg emphasizes the misogynist message of the Surpanakha account:

This encounter indubitably encourages violence against women who are sexual aggressors. It also illustrates, par excellence, the lengths to which men may go to assuage their primal fear of unrestrained female sexuality....

This encounter endorses a social rule with enormous clarity: a sexually reprobate woman must be punished. Violently marking the face, like stamping of the A for adultery on a woman's forehead or stoning to death, is a similarly patriarchal formula to keep women's sexuality in check—on which male honor seems to depend. $^{23}$

Oldenburg concludes that rape may be regarded as a consequence of a woman's uncontrolled desires. ${ }^{24}$

Kathleen Erndl, well-known scholar of Hindu goddess traditions and issues of gender, also calls attention to several interrelated messages or themes in the Surpanakha

\footnotetext{
${ }^{23}$ Veena T. Oldenburg, "Sita's Epic Journey: Reflections on the Violence in the Lives of Hindu Women in North India," in Violence against Women in Contemporary World Religions: Roots and Cures, eds. Daniel C. Maguire and Sa'diyya Shaikh (Cleveland: Pilgrim Press, 2007), 166-167.

${ }^{24}$ Oldenburg, "Sita's Epic Journey," 168.
} 
story that are reflected in Hindu mythology and culture more broadly. She notes, like Oldenburg, that mutilation is widely considered to be an appropriate punishment for women, especially for sexual misbehavior. The slicing off of a woman's nose symbolizes loss of honor, and of her breasts, loss of dangerous power. Accordingly, it is Surpankha's nature as a woman, rather than, or not simply as, a demonness, that is the problem. As the narrator of the Ramcaritamanas warns men: "At the sight of a handsome man, be he her own brother, father, or son..., a woman gets excited and cannot restrain her passion, even as the sun-stone emits fire when it is brought before the sun. ${ }^{25}$

Linda Hess, a Ramlila scholar, points out other misogynistic remarks in the Ramayana. She quotes the words of Rama (from a performance of the Ramlila) to his spiritual mentee Narada, advising him why marriage is not an appropriate state for a would-be sage: "A young woman is the root of all evil, a source of torment, a mine of sorrows. ${ }^{26}$ Hess observed that not only was the sage on the stage delighted, but so also were many of the smiling men in the audience around her. But the women's faces remained expressionless. She asked one woman what she thought of Ram's advice, and after hesitation and glancing at the other Indian women around her, the woman replied, "If Tulsidasji says it, it must be true." ${ }^{27}$ Here is reflected, partially at least, the internalization of the patriarchal values of the Rama story.

\footnotetext{
${ }^{25}$ Quoted in Erndl, "The Mutilation of Surpanakha," 78.

${ }^{26}$ Quoted in Linda Hess, "The Poet, the People, and the Western Scholar: Influence of a Sacred Drama and Text on Social Values in North India," Theatre Journal 40, no. 2 (1988): 239.

${ }^{27}$ Linda Hess "The Poet, the People, and the Western Scholar," 240.
} 
Such internalization is also seen when mothers of rapists protest that their sons are not at fault because what can you expect when a young woman dresses provocatively. As the mother of one of the rapists of the Mumbai photojournalist in August 2013 declared, "Obviously, the fault is the girl's. Why did she have to go to that jungle? It's her fault, too. Also, she was wearing skimpy clothes....Her body was uncovered. How could he control himself?? ${ }^{28}$ Is it surprising, then, for us to find that $24 \%$ of women agree with the notion that a woman who crosses the Lakshman Rekha is at least partially at fault?

Endl draws out several insightful contrasts between the portrayals of Surpanakha, the loose, evil woman, and of Sita, the chaste, good woman, a contrast expressed primarily in terms of sexuality. Sita is controlled by her husband, but Surpankha by no male — no husband, father, son, or brother. Surpanakha is an independent woman. But as Erndl points out, there is a certain male fascination with the loose and dangerous woman, thereby explaining perhaps why Rama and Lakshman toy with Surpanakha before sending her off humiliated. Also significant, Erndl insists, is that Rama punishes Surpankha to protect Sita, the good woman, or as a warning to the good woman as to what could happen to her were she to stray. In a twentieth-century Hindi version of the text, the Radhesyam Ramayan, Rama's order to Lakshmana is justified on the grounds that it was a matter of "duty to punish the wicked....[and thus Lakshmana] disfigured

\footnotetext{
${ }^{28}$ Quoted in Ellen Barry and Mansi Choksi, "Gang Rape in India, Routine and Invisible," The New York Times, October 26, 2013, http://www.nytimes.com/2013/10/27/world/asia/gang-rape-in-india-routine-andinvisible.html?smid=tw-share \&_r=0\&pagewanted=all.
}

Formatted: Default Paragraph Font, Font: (Default) +Body, 10 pt, Not Italic 
Surpanakha in order to keep her away from sin.,29 Thus, Erndl says, we find here a basic mistrust of women by men, whether the women be "good" or "bad."

This mistrust is evident in the story of Sita, who resided in Ravana's house before her rescue. Her residence there has aroused widespread suspicion on the part of many male pundits and also mythical males, including Rama. For "Sita, in the wishful twist of the male imagination, must have given in to her lustful and fickle nature. ${ }^{, 30}$ And in the end, it is not Rama who has to prove his purity but Sita-who must leap into the fire to prove her unswerving fidelity to Rama. As Roy notes, Sita's abduction is the story most commonly cited in discussions of gang-rape, reflecting the common view that women who go out in public are at fault. ${ }^{31}$

As Oldenburg concludes, the Rama-Sita story is not so much about duty or dharma as it is "a tale of sexual transgression, exploitation, suspicion, and tension., ${ }^{, 32}$ She adds: "In pondering the subject I was astonished to find how strongly a two-thousand-year-old story still reflects the construction of gender in contemporary Indian society, with many of the sexual mores and behavioral expectations traceable in the present." ${ }^{, 33}$ She also notes on the positive side the powerful model Sita provides for Indian women today, not just as the ideal good wife, but also as a woman who refuses to remain silent and

\footnotetext{
${ }^{29}$ Translated by and quoted in Erndl, "The Mutilation of Surpanakha," 81.

${ }^{30}$ Oldenburg, "Sita's Epic Journey," 168.

${ }^{31}$ Roy, "Speaking Volumes."

32 Oldenburg, “Sita's Epic Journey,” 170.

${ }^{33}$ Oldenburg, "Sita’s Epic Journey,” 170.
} 
submissive, speaking out against sexual violence and injustice in its various forms. Women today often find in Sita a metaphor for their own miseries inflicted by husbands.

At the same time, the disparagement of women as seen in the Ramcaritamanas' descriptions of the lustful and evil nature of women, while perhaps reflecting only a highcaste assessment of women rather than a general Hindu view, nonetheless through its enormous popularity helps to maintain such derogatory views of women. ${ }^{34}$ These traditional, Brahminical views reflect the attitudes towards women seen in The Laws of Manu, which proclaims:

Drinking, associating with bad people, being separated from their husband, wandering about, sleeping, and living in other people's houses are the six things that corrupt women....By running after men like whores, by their fickle minds, and by their natural lack of affection these women are unfaithful to their husbands even when they are zealously guarded here. ${ }^{35}$

The luxury-loving, lustful, angry, dishonest, and malicious nature of women, Manu adds, Formatted: Font: Italic was instilled in them by the Creator from the beginning.

Such misogynistic views have led feminists in recent years to burn copies of Manu, which in turn has provoked outrage on the part of traditionalist Hindu nationalists. As one 2007 cartoon from the Hindu nationalist organization, the Hindu Janajagruti Samiti (Association for the Awakening of the Hindu People) declares, "Those who do not take

\footnotetext{
${ }^{34}$ Oldenburg, "Sita’s Epic Journey,” 170-172.

${ }^{35}$ The Laws of Manu, with an Introduction and Notes, trans. Wendy Doniger with
} Brian K. Smith (London: Penguin Books, 1991), 9:13, 15. 
any action against the persons who have burnt 'Manusmriti' are equally responsible and they have no right to call themselves Hindus."

For Manu, and apparently for Hindu nationalists who approve of Manu, a woman is to be entirely dependent on male protectors and totally obedient to her husband, worshipping him like a god even if he is without virtue and a philanderer. Accordingly, "[a] virtuous wife should never do anything displeasing to the husband who took her hand in marriage, when he is alive or dead...."37 Thus it would seem that no wife can refuse her husband's sexual advances, her permission supposedly having been given once and for all when she consented to marriage. The persistence of this attitude is seen in response to our survey question asking if "[r]ape cannot take place in a marriage because a husband has sexual rights over his wife. ${ }^{38}$ Seventeen per cent of women and $31 \%$ of men strongly agreed or agreed that marital rape is not possible (see Fig. 10). [Figure 10].

There are of course many other stories in traditional mythology that are problematic aside from those pointed out by Roy. As Indian activist Kancha Ilaiah notes, among various cultural factors contributing to rape culture are political animus, societal conditioning, and religious sagas. Regarding the latter, Ilaiah emphasizes that Indian

\footnotetext{
36 "Shame on Hindus! Manusmruti burnt outside famous Kalaram Mandir," Hindu Janagruti Samiti, http://www.hindujagruti.org/news/3687.html.

${ }^{37}$ The Laws of Manu 5:156.

${ }^{38}$ Question adopted from Patricia W. Easteal, "Belief about Rape: A National Survey," Australian Institute of Criminology, 1992, http://www.aic.gov.au/media_library/publications/proceedings/20/esteal1b.pdf.
} 
society "derives its sense of good and bad from our mythologies and spiritual ethics." "39 Hindus strive to emulate the gods. He then mentions as problematic not only the "divine" actions in the Surpanakha incident, but also such incidents as Lord Krishna's stealing the clothes of women bathing in the Yamuna River, teasing them and enjoying the sight of their naked bodies. Ilaiah concludes, "We hang miniature paintings of the same act in our homes proudly. The young men who grow up seeing this, or listening to the story told in an amused tone are bound to not find such an act abhorrent. $" 40$

\section{Positive portrayals of women in scripture and ancient traditions}

Above we saw that Oldenburg noted a positive view of Sita as a role model beyond that of being a good wife. Roy, like Oldenburg, also takes cognizance of the positive role models that some of the epic heroines provide for today's women. Sita not only speaks out against sexual injustice, she is also a forceful agent in her own right, not just a passive victim. In the ending of Valmiki's Ramayana, Sita, abandoned by Rama due to popular suspicions regarding her "purity," created a life without Rama, raising her children (and his), and eventually rejected Rama, deviating far from the selective and wishful imaginings of contemporary "guardians of the purity of Indian women." ${ }^{41}$ Similarly, Draupadi refused to be treated as property by her husband, who gambled her away,

\footnotetext{
${ }^{39}$ Kancha Ilaiah, “The Roots of Rape in India," Deccan Chronicle.com, May 10, 2013, http://archives.deccanchronicle.com/130510/commentarycolumnists/commentary/roots-rape-india.

${ }^{40}$ Ilaiah, "The Roots of Rape in India."

${ }^{41}$ Roy, "Speaking Volumes."
} 
berating the men on all sides for their acquiescence in her assault. And Amba even goes so far as choosing to be reborn as a man to wreak revenge. Such stories represent "everything about women that terrifies a certain kind of Indian, who prefer to be more selective about the myths they wish to follow." ${ }^{42}$

Perhaps the most positive, or at least most forceful and aggressive portrayals of women/goddesses as independent agents appear in the Puranas or parts thereof focused on the Goddess Durga and her many alternate identities. The celebrated story of the slaying of the demon Mahisha by Durga appears most famously in the Devi-Mahatmya (ca. $5^{\text {th }}$ century) and is retold at length in the Devi-Bhagavata Purana (ca. $12^{\text {th }}-14^{\text {th }}$ centuries).

The Devi-Bhagavata provides an intriguing version that highlights male misinterpretations of female intentions. The demon Mahisha, so the story goes, having conquered all the gods and owning all the wealth in the world, learns about an overwhelmingly beautiful and many-armed woman whom he immediately desires to possess. She is, of course, the Goddess, radiantly charming, fair in all her limbs, but also holding weapons of war in her eighteen hands and drinking wine. Mahisha sends a number of envoys with proposals of marriage, hoping to win her over with gentle words and gifts, but should these prove of no avail, she is to be brought by force, but without hurting her so as not to break the romantic mood. When she refuses each envoy in turn, they offer various reasons to Mahisha for her rejection. One envoy argues that she is just a proud, arrogant woman and drunk to boot, thus not really aware of her helplessness. Another offers a highly eroticized interpretation of the Goddess' response. According to

\footnotetext{
${ }^{42}$ Roy, "Speaking Volumes."
} 
this envoy, when the Goddess said she had come to "lay your master low on the bed of battle," she had really meant she wanted to make love to Mahisha with herself on top and him below. And when she had proclaimed, "I will take away his life force," she was referring to taking his semen virile. The envoy concludes, "That is what she wishes to take from you, nothing else. An excellent woman seeks a husband using words overflowing with innuendo." ${ }^{43}$

In the end, of course, the Goddess destroys the incensed and excited Mahisha and all his allies. One message is certainly clear: "O men, beware when a women says no, even if her words might be twisted to mean yes." Such a warning is relevant today, as seen in our survey, where $25 \%$ of men strongly agreed or agreed with the statement that "Even when a woman says 'no,' she does not really mean it." ${ }^{, 44}$ And almost a quarter of men simply were undecided. Thus only just over half disagreed. Women, too, are not unanimous in rejecting the idea of no meaning yes. Thirteen per cent agreed, but $72 \%$ disagreed, the rest undecided (see Fig. 11). [FIGURE 11].

Goddess stories have inspired many women to protest against male oppression and brutality. Perhaps the most dramatic of these is the real-life story of Phoolan Devi, an outcaste from a village in North India and so-called "Bandit Queen." In 1981 with her gang of men she is reported to have massacred twenty or so high-caste landlords in revenge for the "countless rapes, beatings, tortures, humiliations, incarcerations, and loss

${ }^{43}$ C. Mackenzie Brown, The Triumph of the Goddess: The Canonical Models and Theological Visions of the Devi-Bhagavata Purana (Albany: State University of New York Press, 1990), 108.

${ }^{44}$ Question adopted from Easteal, "Belief about Rape.” 
of loved ones" she had suffered over many years from the hands of such men. ${ }^{45}$ After serving several years in jail for the crimes of her bandit career, she was released to the outrage of some, but was soon elected as a member of parliament, where she served for five years before being assassinated. She was hailed by many of the down-trodden as a heroine, even an incarnation of the goddess Durga. And Phoolan also "saw herself...as the incarnation of Durga, the restorer of dharma, social justice." ${ }^{, 46}$

This motif of the avenging woman in pursuit of justice through identification with the dharma-restoring Durga has penetrated into Bollywood in such films as Anjaam 1994). In this film, the female protagonist Shivani, "a modern, independent woman, with traditional values," transforms from a traditional ideal woman to a fierce avenger, ending up slaying her various tormentors. ${ }^{47}$ She leaves her role as an ordinary and virtuous woman "who simply plays by the rules" to become the divine power (shakti) of the Goddess in order "to destroy the force of evil.," As Erndl notes, "The appeal of this film lies in its deep resonance with the story of the Goddess killing the Buffalo Demon [Mahisha] as found in the Devi-Mahatmya, one of the most popular mythic and ritual

${ }^{45}$ Sarah Caldwell, "Subverting the Fierce Goddess: Phoolan Devi and the Politics of Vengeance," in Playing for Real: Hindu Role Models, Religion, and Gender, eds.

Jacqueline S. Hirst and Lynn Thomas (New Delhi: Oxford University Press, 2004), 161.

${ }^{46}$ Caldwell, "Subverting the Fierce Goddess," 174.

${ }^{47}$ Kathleen M. Erndl, "Woman Becomes Goddess in Bollywood: Justice, Violence, and the Feminine in Popular Hindi Film," Journal of Religion and Film, 17, iss. 2, article 1 (2013): 9, http://digitalcommons.unomaha.edu/jrf/vol17/iss2/1.

${ }^{48}$ Erndl, "Woman Becomes Goddess in Bollywood," 21. 
texts in the Hindu tradition...." ${ }^{49}$ Erndl sums up the significance of this symbolic identification of Shivani and Durga: “...Anjaam displays the 'woman as powerful goddess' image so prevalent in Indian culture, while at the same time presenting a powerful critique of the ways in which that image often fails to translate into women's everyday lives. ${ }^{, 50}$

This disconnection between the worship of goddesses and the abuse of women is highlighted in the controversy surrounding the exhibit of two paintings of goddesses by the artist Eleena Banks at the Mumbai exhibition in the spring of 2013. One portrayed the violent goddess Kali, usually depicted with a garland of skulls lying over her breasts, sans the garland. The other showed a goddess-like figure wearing strawberries, fig-leaf fashion, which according to the artist was to protest the rape of Jyoti several months earlier, apparently by drawing attention to the anatomical part violated by the rapists. As Banks explained: "I wanted to express that the goddess is there in all women, so why do you rape her?" ${ }^{51}$ After protests by Hindu extremists and threats to Bank's life, the paintings were removed. One protestor, Varsha Thakar, a member of the same Hindu Janajagruti Samiti we met earlier, proclaimed "We are not against artistic freedom but

\footnotetext{
${ }^{49}$ Erndl, "Woman Becomes Goddess in Bollywood," 2.

${ }^{50}$ Erndl, "Woman Becomes Goddess in Bollywood," 2.

${ }^{51}$ Quoted in “Artist Receives Threats, Security over Goddess Paintings in Mumbai," NDTV, April 10, 2013, http://www.ndtv.com/article/india/artist-receives-threats-securityover-goddess-paintings-in-mumbai-352570.
} 
would like to know what connection can be drawn between the gang-rape victim and a goddess." 52

Similar controversy swirled around an Indian ad campaign in the fall of 2013 depicting goddesses as victims of domestic violence. As the posters explain, "Today more than $68 \%$ of women in India are victims of domestic violence. Tomorrow, it seems like no woman shall be spared. Not even the ones we pray to. ${ }^{, 53}$ Feminist critics of the campaign pointed out the ambiguous and often problematic nature of identifying women as embodiments of the divine female power or Shakti. The critics saw such identification as depriving women of their own autonomy, individuality, and identity. ${ }^{54}$

Other more conservative critics were concerned about the indignity done to the goddesses. One apparently male commentator complained, "This is like knocking the Goddess off of the pedestal, an indignity piled on women already subjected to excessive abuse. Leave the Goddess alone, let her represent the way women are supposed to be portrayed. ${ }^{, 55}$ Another, from the Hindu Janajagrati Samiti, in a common apologetic tactic,

\footnotetext{
${ }^{52}$ Quoted in "Artist Receives Threats."

${ }^{53}$ Quoted in ““Abused Goddesses' Shows Shocking Images of Hindu Deities for
} Campaign against Domestic Violence in India (PHOTOS)," Huff Post: Religion,

September 6, 2013, http://www.huffingtonpost.com/2013/09/06/abused-goddessescampaign-domestic-violence-india_n_3880515.html.

${ }^{54}$ Reshmi K. Oberoi, “Critics Slam Art that Depicts Abused Indian Goddesses, Raises Awareness for Domestic Violence," Huff Post: Impact, October 25, 2013, http://www.huffingtonpost.com/2013/10/25/abused-goddess-campaign_n_4164256.html.

${ }^{55}$ Comment responding to Oberoi, "Critics Slam Art." 
grumbled that non-Hindus also abuse women in India, and then added, "However, this ad campaign specifically blames the Hindu society for the atrocities. To get their message across, the ad-makers have depicted Hindu Deities in a disrespectful manner. This reeks of sheer anti-Hindu bias!" ${ }^{56}$ And from the same web page: "Rulers, police and social conditions are responsible for the persecution of women in any society. Instead of taking these responsible elements to task, why are Hindu Goddesses being depicted in an insulting manner?"

There is certainly much truth in this last statement regarding the political and social conditions contributing to rape-at least many of our survey respondents would agree. In response to our question regarding possible contributing factors to rape in India, overwhelming majorities (66\% to $88 \%$ ) of men and women agreed that political and police corruption, politicians and policemen who themselves have committed rape, inadequate laws protecting women, inadequate law enforcement, an overwhelmed judicial system, and inadequate punishment for convicted rapists were all significant factors (see Table 1). Among other factors listed on the survey, only a small majority (56\% for women and $54 \%$ for men) saw a too permissive society as a contributing factor to India's rape-tolerant culture. In any case, our respondents clearly take "these responsible elements to task" as the Hindu Janajagrati Samiti blogger above advocates.

\footnotetext{
56 “Protest: 'Abused Goddesses’ Campaign Condemning Domestic Violence Denigrate Hindu Deities,” Hindu Janagruti Samiti, September 12, 2013, http://www.hindujagruti.org/news/17352_abused-goddesses-campaign-denigrate-hindudeities.html.
} 
However, $74 \%$ of women and $67 \%$ of men (with only $3 \%$ and $5 \%$, respectively, disagreeing) saw still another important factor: "Inadequate sensitization of boys and young men to issues of gender." This last finding points to various cultural factors, including possibly the status of women vis-à-vis goddess images, which are not in opposition to political and police corruption but go hand in hand with it. Are the battered goddess images really "insulting," or are they rather calling attention in dramatic fashion to the hypocrisy of Indian men who batter their wives while honoring the goddesses? [TABLE 1]

The various critiques of the ad campaign notwithstanding, the disjunction between the divine feminine and women both in the flesh and in the negative portrayals of women in the sacred traditions, is quite troubling. Negative representations of women in religious literature, of course, are not the sole cause for violence against women in a given culture, as we have just seen. In the concluding section, we will consider very briefly theories that look at the larger context in which such sexual violence erupts, the sort of violence that claimed the life of Jyoti Singh Pandey.

\section{Why do some men rape? Why did Jyoti die?}

The sexual violence against Jyoti raises two questions. First, and long debated in the scholarly literature since Susan Brownmiller's pioneering book, Against Our Will: Men, Women, and Rape (1975), is why do some men rape. And second is why do some rapists mutilate the genitalia of their rape victims. This latter question, receiving increasing scholarly attention, is particularly relevant to Jyoti's case, the brutality of her attackers 
being one contributing factor to the huge protests around the country. But first, let us focus on the question regarding why some men rape.

One question of our survey listed a number of possible reasons, biological, psychological, and social, for why men rape (see Table 2). Women strongly favored while men somewhat favored these biological and psychological reasons:

- "inherent male nature" (79\% of women; 55\% of men),

- "sexual frustration" ( $89 \%$ of women; $81 \%$ of men),

- "desire or need to prove manliness" ( $82 \%$ of women; $58 \%$ of men), and

- "desire to exercise power over women" (74\% of women; $54 \%$ of men).

"Hatred or fear of women" was favored by less than half of women (45\%), and by less than one third of men (30\%). Social factors such as low social status were favored by less than half ( $48 \%$ of women; $44 \%$ of men), while poverty was favored by still fewer (35\% of women; $29 \%$ of men). Social/cultural conditioning in general, however, was favored by relatively small but significant majorities of both women (58\%) and men (51\%).

\section{[TABLE 2]}

While the various reasons we put into our survey reflected our own familiarity with the reasons discussed in the scholarly literature, the survey data tend to confirm the growing consensus that the reasons for rape involve a number of multiple interacting factors, although our respondents give more weight to the biological than to the social and cultural factors increasingly favored by scholars.

The British historian of medicine, Roy Porter, writing more than a quarter of a century ago, provides an insightful overview of various early competing theories 
purporting to explain rape. ${ }^{57}$ Among these, naturally, was Brownmiller's: rape is basically a political act, part of a male strategy to enforce and perpetuate patriarchy. Porter contends, however, that patriarchy was sufficiently well established in Europe without rape so that men in power saw the rapist as a threat against their own authority, not as justification for patriarchal oversight of women. ${ }^{58}$ Porter also notes Edward Shorter's theory, that rape is "a sex offense, an act of libidinal release,...[a way of coping] with sexual frustration in the highly repressive communities of the pre-industrial past. ${ }^{, 59}$ Porter dissents from Shorter's view, seeing it as too simplistic, arguing that "it is better to view sexuality as shaped by culture, values and social habit.... ${ }^{60} \mathrm{He}$ then notes the findings of anthropologist Peggy Reeves Sanday regarding contemporary societies

${ }^{57}$ Roy Porter, “Rape—Does It Have a Historical Meaning?" in Rape, eds. Sylvana Tomaselli and Roy Porter (Oxford: Basil Blackwell, 1986), 216-236, 270-279.

${ }^{58}$ Porter, “Rape,” 223.

${ }^{59}$ Porter, “Rape,” 218-219.

${ }^{60}$ Porter, "Rape," 219. See also Caterina Gironda, "Rethinking Rape: Moving Beyond the Social vs. Biological," Zeteo: The Journal of Interdisciplinary Writing, November 15, 2012, http://zeteojournal.com/wp-content/uploads/2012/11/Cat-Rapefinal-14-Nov-2.pdf. Gironda calls for "a theory that accounts for the psychological and cultural as well as for the physical impetuses for rape. By understanding that we cannot separate the mind from the body—by recognizing that the brain-mind is both a physical part of our body and the source of our psychology—we can realize that the physical act of rape is intertwined with the psychology behind it and the environment surrounding it." 
with relatively low levels of sexual activity, low rates of rape, and no evidence of sexual frustration.

In his concluding remarks, Porter suggests that rape culture flourishes "on the margins" of society, including not only on the margins of civilized society (on the frontiers, in war), but also "on the psycho-margins, amongst loners, outsiders, who fail to be encultured into normal patriarchal sex. Above all, rape has marked youth sub-cultures, on the criminal margins." ${ }^{\prime 61}$ These young males "lack the permanent erections of mature patriarchy-wealth, property, office, 'standing.",62 Unless these unassimilated males are integrated into the work force or sent off to war, they become the "waste of patriarchy...not its shock troops...but a diseased excrescence." ${ }^{, 63}$

Complementing Porter's views, the Harvard evolutionary psychologist Steven Pinker, commenting on the Delhi gang-rape in particular, sees it as manifesting one extreme of men's sexuality. He notes that in more stable social environments men

${ }^{61}$ Porter, "Rape," 235.

${ }^{62}$ Porter, "Rape," 235.

${ }^{63}$ Porter, "Rape," 235. See also Steven Pinker, The Better Angels of Our Nature: Why violence has Declined (New York: Viking, 2011), 68. Pinker dismisses Brownmiller's "myrmidon theory" of rapists—-that rapists are the mercenary soldiers perpetuating patriarchy—as "preposterous. Not only does it elevate rapists to altruistic troopers for a higher cause, and slander all men as beneficiaries of the rape of the women they love, but it assumes that sex is the one thing that no man will ever use violence to attain, and it is contradicted by numerous facts about the statistical distribution of rapists and their victims." 
seeking sexual partners generally resort to such non-violent means as propositioning and seduction. But

in unregulated settings and when men are desperate, low in empathy and selfcontrol, it can lead to harassment and rape. This can be exacerbated in cultures that practise female-selective infanticide. That leaves large numbers of unattached men, generally poor and marginalised, who prey for sexual opportunities. ${ }^{64}$

The issue of female-selective infanticide, as noted by Valerie M. Hudson and Andrea M. Den Boer, is the tragic consequence of "son-preference and the profound devaluation of female life." ${ }^{65}$ Hudson and Den Boer, social scientists renowned for their pioneering

${ }^{64}$ Steven Pinker, as quoted in an interview by Srijana M. Das, "Steven Pinker: US Women's Rights Movements Made Lawmakers Treat Rape Seriously," The Times of India, January 14, 2013,

http://timesofindia.indiatimes.com/home/opinion/interviews/Steven-Pinker-US-womensrights-movement-made-lawmakers-treat-rape-seriously/articleshow/18010789.cms.

${ }^{65}$ Valerie M. Hudson, and Andrea M. Den Boer, "Bare Branches and Security in Asia," Harvard Asia Pacific Review 9, iss. 1 (2007): 19, http://www.hcs.harvard.edu/ hapr/winter07_gov/hudson.pdf. See also Sen, "India's Women." Sen argues that the brutal gang-rape of Jyoti must be understood within the context of the specific "nature of female disadvantage in India," and he calls attention to "the old phenomenon of 'boy preference' in family decisions." Sen further notes that even educated mothers have strong preferences for sons, as these women seem to have little awareness of the "oddity of seeing girls as inferior to boys." Sen calls for "scrutiny of traditional values" as central to any solutions to the problem of missing women. 
research on international security implications of imbalanced sex ratios, especially in China and India, reinforce Pinker's analysis, arguing that

men who are not provided the opportunity to develop a vested interest in a system of law and order will gravitate toward a system based on physical force, in which they hold an advantage over other members of society. Furthermore...in a system with too few women, the men who marry are those who are higher in socio-economic status. The men who will not be able to marry are those who are poorer, less educated, less skilled, and less likely to be employed. These men are already at risk to establish a system based on physical force in order to obtain by force what they cannot obtain legitimately. ${ }^{66}$

Hudson and Den Boer, with reference to India, point out that states with high male to female sex ratios, such as Uttar Pradesh in the north, have more violent crime (including sexual crimes) than states with more balanced sex ratios. Nilanjana Roy applies the insights of Hudson and Den Boer to explain, specifically, the high incidence of violent crime, including sexual assault, in the Dehli-Gurgaon area, where Jyoti Singh Pandey was gang-raped ${ }^{67}$ Chaudhury's comment on Jyoti's six rapists is relevant here:

\footnotetext{
${ }^{66}$ Valerie M. Hudson, and Andrea M. Den Boer, "Missing Women and Bare Branches: Gender Balance and Conflict,” ECSP Report 11 (2005): 21-22, http://www.wilsoncenter.org/sites/default/files/Hudson\%2526denBoer.pdf.

${ }^{67}$ Nilanjana Roy, commentary in "How Do We Stop Rapes? India Looks for Answers," Tehelka.com, June 20, 2013, http://tehelka.com/delhi-gangrape-outragedindia-reacts/?singlepage $=1$.
} 
One can imagine how the booze must have smudged their heads, erased the squalor of their lives, made them feel zesty, reckless, bold. It uncorked a deadly cocktail boiling inside them. They were sick of being matchstick men, sick of the shining alien city always bustling outside their reach. They wanted a piece of the action. They wanted to feel like kings of the road. ${ }^{68}$

Particularly problematic, as illustrated by the Delhi gang-rape, is the banding together of marginalized young men, increasing their capacity for violent crime. Hudson and Den Boer call attention to studies demonstrating that "the behavior of men in groups-most particularly young, single, low-status males-will not rise above the behavior of the worst behaved individual," exacerbating the degree of violence they would be willing to commit as individuals. ${ }^{69}$ Indeed, of the six rapists, only the eldest, Ram Singh, leader of the gang, had a history of violence. ${ }^{70}$

Yet Ram Singh himself, according to his mother, "worshipped all Hindu gods,,"71 and his younger brother Mukesh, another of the rapists, was considered "a mild young man" whose marriage had just been arranged by his parents. ${ }^{72}$ Nonetheless, all six came

\footnotetext{
${ }^{68}$ Chaudhury, "The Girl who Fired an Outcry."

${ }^{69}$ Valerie M. Hudson and Andrea M. Den Boer, “A Surplus of Men, A Deficit of
} Peace: Security and Sex Ratios in Asia's Largest States," International Security, 26, no. 4 (2002): 15,

http://belfercenter.ksg.harvard.edu/files/hudson_and_den_boer_spring_2002.pdf.

\footnotetext{
${ }^{70}$ Chaudhury, "The Girl who Fired an Outcry."

${ }^{71}$ Schulz and Wagner, "Rape Tragedy in India."

${ }^{72}$ Chaudhury, "The Girl who Fired an Outcry."
} 
from a background of urban poverty, "a deadly landscape of squalor and hope and thwarted ambition.,73

The interactions between populations with surplus young men, son-preference, economic considerations, social standing, and social-religious constructions of gender relations are complex. Clearly, patriarchal attitudes can contribute to a strong cultural preference for sons and the devaluing of women generally. Equally clearly, sacred traditions often (but not always) both reflect and perpetuate misogynistic attitudes. Veena Oldenburg cites one example from the Ramayana, involving the "birth" of Sita: "In contrast to the much-heralded male births [of Rama, Lakshmana, and so forth], it is interesting how Sita is introduced to this world as a foundling. She lies in a furrow of a field. ${ }^{, 74}$ While tradition has come to interpret this as a divine birth from Mother-Earth, Oldenburg was troubled by it even as a child. Now, as a grown Indian woman, she finds more disturbing implications:

In the precolonial and colonial period we know that the killing of unwanted female infants was widespread and in flagrant transgression of religious law that considers it the most heinous of crimes. A common method was to simply expose the newborn to the elements, in a distant field where she would die of cold and starvation. Was Sita abandoned as an infant by a family who did not want her and hoped that she would be found by Janak, the king of Vadeha, as he tilled his field during the seasonal ritual $?^{75}$

\footnotetext{
${ }^{73}$ Chaudhury, "The Girl who Fired an Outcry."

${ }^{74}$ Oldenburg, "Sita's Epic Journey,” 161.

${ }^{75}$ Oldenburg, "Sita’s Epic Journey,” 161.
} 
While the Ramayana hardly advocates selective female infanticide-even if it may reflect the practice in Sita's case - the almost total ignoring of the lives of the prominent women figures until they are wives, unlike the detailed accounts of the childhood and adolescence of the male protagonists, cannot help but promote a system of values that debases the lives of women. Such devaluing of women is quite evident in the story of the mutilation of Surpanakha-a loose woman who must be punished. Her treatment brings us to our second question: why do some rapists mutilate the genitalia of their rape victims.

Martha C. Nussbaum, scholar of gender and human rights issues, offers some suggestive answers deriving from her study of the Gujurat riots of 2002 when more than 2,000 Muslims were killed, many of the victims being women and children. ${ }^{76}$ And many of the women were gang-raped and then mutilated by having their bellies ripped open or metal rods inserted up their vaginas into their stomachs, before being burnt. ${ }^{77}$ Nussbaum notes the Hindu nationalistic factors contributing to these atrocities but calls attention especially to the phenomenon of disgust present in all cultures. Drawing on the work of the feminist Andrea Dworkin, Nussbaum sees in the Gujurat mutilations the mixing of

\footnotetext{
${ }^{76}$ Martha C. Nussbaum, "Body of the Nation: Why Women Were Mutilated in Gujarat,” Boston Review, July 29, 2004, http://www.countercurrents.org/gujnussbaum290704.htm.

${ }^{77}$ These tortures and mutilations are described by Tanika Sarkar, "Semiotics of Terror: Muslim Children and Women in Hindu Rashtra,"Economic \& Political Weekly 37, iss. 28 (July 13, 2002): 2875, http://www.jstor.org/stable/4412352.
} 
"male desire... with the desire to violate and destroy." ${ }^{78}$ She explains this paradoxical and horrific mixture of desires by relating it to the emotion of disgust, which men all too often associate with women perceived merely as "receptacles of male emissions as well as the fluids associated with menstruation and birth....",79 Women are thus "portrayed as sticky, smelly, dirty, repellent." ${ }^{80}$ Nussbaum adds that males who hold such views "are revolted by the idea of their semen inside a woman's vagina, and yet they can't keep from wanting to put it there. ${ }^{, 81}$ The resulting feelings of being sullied and disgusted reinforce a radical objectification of women which readily turns violent. As Nussbaum concludes, the very understanding of dominant masculinity that makes all reminders of animality disgusting is deeply threatened by sexual desire for women. The man sees, in his desire, that he is not who he pretends to be: he is an animal wanting to exercise animal functions. This deep wound to his ego can only be salved by destroying the cause of his desire. ${ }^{82}$

While there may be other explanatory theories for why some rapists mutilate the genitalia of their victims, Nussbaum's seem quite compelling. How else can one explain the extreme brutality that Jyoti endured? Or the disfigurement of Surpanakha that

\footnotetext{
${ }^{78}$ Nussbaum, "Body of the Nation.” Nussbaum, incidentally, criticizes Dworkin's "representation of disgust misogyny as ubiquitous and inevitable," rather than as dependent upon cultural and individual variations.

${ }^{79}$ Nussbaum, "Body of the Nation."

${ }^{80}$ Nussbaum, "Body of the Nation."

${ }^{81}$ Nussbaum, "Body of the Nation."

${ }^{82}$ Nussbaum, "Body of the Nation."
} 
included, in some versions, the cutting off of her breasts? Nussbaum's insights help to synthesize the various biological, cultural, and social factors that underlie such tragedies.

\section{Conclusion}

The Hindu sacred traditions do not in themselves, of course, create tragedies like the rape and mutilation of Jyoti Singh Pandey. But at times they do reflect and perpetuate the misogynistic perspectives underlying the extreme objectification of women that facilitate such assaults. Those parts of the sacred tradition that contribute to such perspectives need to be recognized, critiqued, and rejected, not accorded the status of some divine norm for male behavior and attitudes.

There are many portrayals of women, and of sexuality, in the traditions that are useful and helpful to women. Aside from the image of the violent and aggressive goddess figures like Durga, the justice-invoking character of Draupadi, and the independent and assertive Sita, there are also positive erotic images of both men and women. These latter reflect what the Indian psychoanalyst Sudhir Kakar calls "the Indian combination of religiosity and eroticism" as manifest not only in the Kama Sutra but also in poetry and carvings such as at the temples at Khajuraho and Orissa-images that are an embarrassment to many contemporary Indians "influenced by a colonial Victorian morality. ${ }^{\circ 3}$ In a recent response specifically to the gang-rape of Jyoti Pandey Singh, Kakar argues that in the process of imitating Western mores in film and fashion, India is losing sight of its own traditional core values such as the "ideal of the body as a temple

\footnotetext{
${ }^{83}$ Sudhir Kakar, "Virtue and Pleasure," Outlook India.com, September 11, 1996, http://www.outlookindia.com/printarticle.aspx?202090.
} 
that must never be desecrated." At the same time, Kakar calls for assimilating the western ideals of "the unending search and respect for knowledge and the notion of universal human rights, which will help us to revitalize our own Indian civilisation.” And more specifically, he adds, "The idea of full equality of women and their social emancipation, especially in the erotic sphere, is to be welcomed and advanced with all the strength at our command." $\$ 4$

The rejection of the traditional negative images and the fore-fronting of the positive seem to be essential parts of the campaign to stop "sexual terrorism," as called for by the universal "no-sign" at the bottom of the Delhi-Gurgaon billboard. The figures of such proud and defiant, if long-suffering, women as Draupadi and Sita can serve to banish the notion that women who are assaulted or raped bring dishonor to themselves or their families. It is tragic that among our respondents, $25 \%$ of the women and $35 \%$ of the men agreed or strongly agreed that a rape victim brings dishonor to her family (see Fig. 12). While such views point to the persistence of ancient literary and religious paradigms, the survey data also point to the large number of young Indians who reject the hoary misogynistic messages, and who support the campaign to stamp out sexual terrorism. [FIGURE 12]

One of the more encouraging signs of the massive protests in the wake of Jyoti's death and the continued media attention to sexual assaults, however, is that more women seem willing to come forth and talk about rape, their own and others. And as Agrawal

\footnotetext{
${ }^{84}$ Sudhir Kakar, comment in "How do We Stop Rapes? India Looks for Answers," Tehelka.com, December 20, 2012, http://www.tehelka.com/delhi-gangrape-outragedindia-reacts/?singlepage $=1$.
} 
discovered, women want to talk about it, if given the appropriate opportunity. We conclude with one of the most moving comments she received from a woman interviewed in Mumbai. Following the formal session, this woman approached, tearyeyed, and asked if she could hug Agrawal. She then declared, quite simply, "Thank you for making me believe today, that I too am a respectable woman.”

\section{Bibliography}

Abdulali, Sohaila. “I Was Wounded; My Honor Wasn't.” New York Times, January 07, 2013. http://www.nytimes.com/2013/01/08/opinion/after-being-raped-i-waswounded-my-honor-wasnt.html.

““Abused Goddesses' Shows Shocking Images of Hindu Deities for Campaign against Domestic Violence in India (PHOTOS).” Huff Post: Religion, September 6, 2013. http://www.huffingtonpost.com/2013/09/06/abused-goddesses-campaigndomestic-violence-india_n_3880515.html.

Anand, Jatin. "Delhi Rape: Juvenile Raped Woman Twice and Ripped Off Her Intestine.” Hindustan Times, January 03, 2013. http://www.hindustantimes.com/indianews/chunk-ht-ui-indiasectionpage-delhigangrape/delhi-rape-juvenile-rapedwoman-twice-and-ripped-off-her-intestine/article1-984188.aspx.

“Artist Receives Threats, Security over Goddess Paintings in Mumbai.” NDTV, April 10, 2013. http://www.ndtv.com/article/india/artist-receives-threats-security-overgoddess-paintings-in-mumbai-352570.

Barry, Ellen and Mansi Choksi. "Gang Rape in India, Routine and Invisible.” The New York Times, October 26, 2013. 
http://www.nytimes.com/2013/10/27/world/asia/gang-rape-in-india-routine-andinvisible.html?smid=tw-share\&_r=0\&pagewanted=all.

"BJP Leader Quotes Ramayana, Says Women Who Cross Limits Pay the Price," IBN Live, January 04, 2013, http://ibnlive.in.com/news/bjp-leader-quotes-ramayanasays-women-who-cross-limits-pay-the-price/313761-37-64.html.

Brown, Mackenzie, C. The Triumph of the Goddess: The Canonical Models and Theological Visions of the Devi-Bhagavata Purana. Albany: State University of New York Press, 1990.

Bulaia, Urvashi. "Let's Ask How We Contribute to Rape.” The Hindu, October 02, 2013. http://www.thehindu.com/opinion/op-ed/lets-ask-how-we-contribute-torape/article4235902.ece.

Caldwell, Sarah. "Subverting the Fierce Goddess: Phoolan Devi and the Politics of Vengeance." In Playing for Real: Hindu Role Models, Religion, and Gender, edited by Jacqueline S. Hirst and Lynn Thomas, 161-178. New Delhi: Oxford University Press, 2004.

Chaudhury, Shoma. "Rape, and How Men See It.” Tehelka.com, January 19, 2013. http://www.tehelka.com/cover-story-rape-and-how-men-see-it/.

—. "The Girl Who Fired an Outcry in India." Tehlka.com, April 04, 2013. http://www.tehelka.com/the-girl-who-fired-an-outcry-in-india/.

Das, Srijana, M. “Steven Pinker: US Women's Rights Movements Made Lawmakers Treat Rape Seriously.” The Times of India, January 14, 2013. http://timesofindia.indiatimes.com/home/opinion/interviews/Steven-Pinker-US- 
womens-rights-movement-made-lawmakers-treat-rape-

seriously/articleshow/18010789.cms.

"Delhi Gangrape Victim as Guilty as Rapists: Asaram Bapu.” Firstpost.India, January

07, 2013. http://www.firstpost.com/india/delhi-gangrape-victim-as-guilty-asrapists-asaram-bapu-579560.html.

“Delhi Gangrape: Asaram Bapu Holds Girl Responsible, Says 'Spare' Rapists, Slams Media." The Indian Express, March 11, 2013.

http://archive.indianexpress.com/news/asaram-bapu-holds-victim-responsible-fordelhi-gangrape/1055639/.

Devi, Mahasveta. "Draupadi.” Translated by Gayatri Chakravorty Spivak. Critical Inquiry, 8, no. 2 (1981): 381-402.

Easteal, Patricia, W. "Belief about Rape: A National Survey.” Australian Institute of Criminology, 1992.

http://www.aic.gov.au/media_library/publications/proceedings/20/esteal1b.pdf.

Erndl, Kathleen, M. “The Mutilation of Surpanakha.” In Many Ramayanas, The Diversity of a Narrative Tradition in South Asia, edited by Paula Richman, 68-85.

Berkeley: University of California Press, 1991.

http://publishing.cdlib.org/ucpressebooks/view?docId=ft3j49n8h7\&chunk.id=d0e

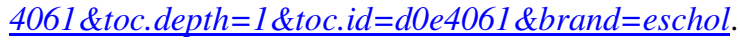

—. "Woman Becomes Goddess in Bollywood: Justice, Violence, and the Feminine in Popular Hindi Film." Journal of Religion and Film 17, iss. 2, article 1 (2013):130, http://digitalcommons.unomaha.edu/jrf/vol17/iss2/1. 
Falerio, Sonia. “The Unspeakable Truth about Rape in India.” The New York Times, January 01, 2013. http://www.nytimes.com/2013/01/02/opinion/the-unspeakabletruth-about-rape-in-india.html?ref=opinion\&_r=0.

Gironda, Caterina. "Rethinking Rape: Moving Beyond the Social vs. Biological." Zeteo: The Journal of Interdisciplinary Writing, November 15, 2012. http://zeteojournal.com/wp-content/uploads/2012/11/Cat-Rape-final-14-Nov2.pdf.

Hess, Linda. “The Poet, the People, and the Western Scholar: Influence of a Sacred Drama and Text on Social Values in North India.” Theatre Journal 40, no. 2 (1988): 236-253.

Hudson, Valerie, M. and Den Boer, Andrea, M. “A Surplus of Men, A Deficit of Peace: Security and Sex Ratios in Asia's Largest States.” International Security 26, no. 4 (2002): 5-38.

http://belfercenter.ksg.harvard.edu/files/hudson_and_den_boer_spring_2002.pdf.

—. "Missing Women and Bare Branches: Gender Balance and Conflict." ECSP Report 11 (2005): 20-24.

http://www.wilsoncenter.org/sites/default/files/Hudson\%2526denBoer.pdf.

—. "Bare Branches and Security in Asia." Harvard Asia Pacific Review 9, iss. 1 (2007): 18-20. http://www.hcs.harvard.edu/ hapr/winter07 gov/hudson.pdf.

Ilaiah, Kancha. “The Roots of Rape in India,” Deccan Chronicle.com, May 10, 2013, http://archives.deccanchronicle.com/130510/commentarycolumnists/commentary/roots-rape-india 
Kakar, Sudhir. "Virtue and Pleasure.” Outlook India.com, September 11, 1996.

http://www.outlookindia.com/printarticle.aspx?202090.

—. "How do We Stop Rapes? India Looks for Answers." Tehelka.com, December 20, 2012. http://www.tehelka.com/delhi-gangrape-outraged-india-

$\underline{\text { reacts } / \text { ?singlepage }=1}$.

Lakshmi, Rama. “Amid Rape Fiasco, India’s Leaders Keep Up Insensitive Remarks.”

The Washington Post, January 04, 2013.

http://www.washingtonpost.com/blogs/worldviews/wp/2013/01/04/amid-rapefiasco-indias-leaders-keep-up-insensitive-remarks/.

Marin, Alex. "Jyoti Singh Pandey: Gang Rape Victim Dying Declaration to Doom

Perpetrators.” PolicyMic, January 12, 2013.

http://www.policymic.com/articles/22727/jyoti-singh-pandey-gang-rape-victimdying-declaration-to-doom-perpetrators.

"MP Minister Kailash Vijayvargiya Wins Sixth Election in Row." Zeenews, December 08, 2013. http://zeenews.india.com/assembly-elections-2013/madhya-pradeshpolls/mp-minister-kailash-vijayvargiya-wins-sixth-election-in-row_895311.html.

Nelson, Dean. "Delhi Gang-rape Victim to Haunt Attackers with 'Dying Declaration."”

The Telegraph, January 11, 2013.

http://www.telegraph.co.uk/news/worldnews/asia/india/9796076/Delhi-gangrape-victim-to-haunt-attackers-with-dying-declaration.html.

Nussbaum, Martha, C. "Body of the Nation: Why Women Were Mutilated in Gujarat." Boston Review, July 29, 2004. http://www.countercurrents.org/gujnussbaum290704.htm. 
Oberoi, Reshmi, K. “Critics Slam Art that Depicts Abused Indian Goddesses, Raises Awareness for Domestic Violence.” Huff Post: Impact, October 25, 2013. http://www.huffingtonpost.com/2013/10/25/abused-goddesscampaign_n_4164256.html.

Oldenburg, Veena, T. "Sita's Epic Journey: Reflections on the Violence in the Lives of Hindu Women in North India." In Violence against Women in Contemporary World Religions: Roots and Cures, edited by Daniel C. Maguire and Sa'diyya Shaikh, 153-173. Cleveland: Pilgrim Press, 2007.

Pinker, Steven. The Better Angels of Our Nature: Why Violence has Declined. New York: Viking, 2011.

Porter, Roy. “Rape—Does It Have a Historical Meaning?" In Rape, edited by Sylvana Tomaselli and Roy Porter, 216-236, 270-279. Oxford: Basil Blackwell, 1986.

“Protest: 'Abused Goddesses' Campaign Condemning Domestic Violence Denigrate Hindu Deities.” Hindu Janagruti Samiti, September 12, 2013.

http://www.hindujagruti.org/news/17352_abused-goddesses-campaign-denigratehindu-deities.html.

"Rapes Happen in India, Not Bharat: RSS Chief Mohan Bhagwat Blames Western Culture for Gangrapes.” Indiatoday, January 04, 2013. http://indiatoday.intoday.in/story/rapes-happen-in-india-not-bharat-rss-chiefmohan-bhagwat-blames-western-culture-for-gangrapes/1/240709.html.

Roy, Nilanjana. "Speaking Volumes: A Woman Alone in the Forest." nilanjanaroy.com, January 08, 2013. http://nilanjanaroy.com/2013/01/08/speaking-volumes-womain-the-forest $/$. 
—. "How Do We Stop Rapes? India Looks for Answers." Tehelka.com, June 20, 2013.

http://tehelka.com/delhi-gangrape-outraged-india-reacts/?singlepage=1.

"RSS Chief Criticised for 'Rapes Happen in India, Not Bharat.”' Firstpost.Politics, January 04, 2013. http://www.firstpost.com/politics/rss-chief-criticized-for-rapeshappen-in-india-not-bharat-comment-577946.html?utm_source=ref_article.

Sarkar, Tanika. "Semiotics of Terror: Muslim Children and Women in Hindu

Rashtra."Economic \& Political Weekly 37, no. 28 (July 13, 2002): 2872-2876. http://www.jstor.org/stable/4412352.

Schulz, Sandra and Wieland Wagner. "Rape Tragedy in India: Dreams of 'the Fearless One.”" Spiegel Online International, January 25, 2013. http://www.spiegel.de/international/world/exploring-the-lives-of-the-rape-victimand-suspects-in-india-a-879187.html.

Sen, Amartya. "India's Women: The Mixed Truth." The New York Review of Books, October 10, 2013. http://www.nybooks.com/articles/archives/2013/oct/10/indiaswomen-mixed-truth/.

"Shame on Hindus! Manusmruti burnt outside famous Kalaram Mandir." Hindu Janagruti Samiti. http://www.hindujagruti.org/news/3687.html.

The Laws of Manu, with an Introduction and Notes. Translated by Wendy Doniger with Brian K. Smith. London: Penguin Books, 1991. 